A könyv az ismeretterjesztô pszichológiai irodalom egyre szaporodó kínálatát gazdagítja. Témája többoldalú körüljárása és az idézett kísérletek bôséges kínálata folytán szakemberek is haszonnal forgathatják, oktatásban és tanácsadó munkában egyaránt felhasználhatják. Szerzóje gazdaságpszichológiával és döntéselmélettel foglalkozó kutató.

A választás paradox pszichés hatását elemezve a filozófus Berlinre hivatkozva megvilágítja, hogy létezik negatív szabadság, amely a korlátoktól való mentességet jelenti, és pozitív szabadság, azaz a cselekvés szabadsága, annak a lehetôsége, hogy teljes és értelmes életet éljünk. Ha tehát a korlátok ledólnek, az még nem jelenti automatikusan a teljes és értelmes életet, ahhoz fel kell nóni. Az autonómia nem önmagában javít az életünkön. A szerzó ismerteti Seligman tanult tehetetlenséggel és depresszióval kapcsolatos elméletét, amelyból azt szúrhetjük le, hogy a depresszió kivédése céljából általában a helyzetek kontrolljára törekszünk. Azonban, ha a kontroll mértéke, azaz a választási szabadság és az azzal járó felelősség meghaladja pszichés teherbíró képességünket, úrrá lesz rajtunk a szorongás. Minél több lehetôségünk van arra, hogy kezünkbe vegyük sorsunkat, annál nagyobb elvárásokat is támasztunk önmagunkkal szemben, ez pedig megint fokozza a szorongást. 
A jó döntéshez az szükséges, hogy mindegyik választási lehetőségról elegendô információval rendelkezzünk. A szerzó ecseteli a túl sok információ erdejében való tájékozódás nehézségét, amelynek megint kontrollvesztés a végeredménye. Azt azonban nem fejti ki, hogy éppen ennek kivédése érdekében sokszor magunk redukáljuk az információkat: néhányat befogadunk, azokról elhisszük vagy elhitetjük magunkkal, hogy a döntéshez a legfontosabbak, és minden mást elhárítunk. Úgy törekszünk a kontroll érzésére, hogy azt gondoljuk, minden lényeges információ birtokában vagyunk, és tovább már nem is kell tájékozódni - így valójában csökkentjük a kontroll lehetóségét.

Döntési helyzetekre a könyv szerzóje többek között ilyen praktikus tanácsokat ad:

- a legjobb helyett keressük csak az "elég jót",

- döntéseink nyomán ne várjunk csodát,

- ne attól függóen döntsünk, hogy mások mit tesznek.

A maximalizálással kapcsolatban mellékel egy, az Amerikai Pszichológiai Társaság közremúködésével készült kérdôívet, amellyel minden olvasó tesztelheti önmagát. Rengeteg kereskedelmi példát hoz, és a tapasztalatlanabb vásárlóknak valóban nagy hasznára lehet, hogy a kereskedók csábítási trükkjeire is felhívja a figyelmet.

A szerzô szerint a maximalizálás ellen józan belátással még valamennyire tudunk tenni, de sokkal kevésbé tudjuk ellenórizni és fékezni a bennünk munkáló társadalmi összehasonlítást. A státusért folytatott küzdelem és versengés olyan erôs, hogy fontosabb az összehasonlításból gyôztesen kikerülni, mint saját mércénkhez képest jónak lenni, és a magunk szempontjából jól választani. Lehet, hogy ez a szemlélet a társadalmi egyenlótlenségek fokozódásával már hazánkban is eluralkodott?

A szerzó részletesen bemutatja, hogy bármilyen érzelmi feszültség (szorongás, depresszió, düh, sürgetettség, túlterheltség) rossz döntéshez vezethet, mert a feszültség redukciójára törekedve talán elhamarkodottan választunk.

Hiányolom az eszmefuttatásokból a Festinger-féle kognitív disszonancia-elmélet kifejtését, hiszen annak nagyon is gyakorlati következményei vannak, amelyeket a mindennapokban tapasztalunk. Ha egyszer már választottunk, mindenáron azt akarjuk bizonygatni, hogy az jó döntés volt. Ha megbántuk, igyekszünk a negatív következményeket tompítani, letagadni, szőnyeg alá söpörni, mert azok veszélyeztetik önértékelésünket. Nagy éneró szükséges ahhoz, hogy beismerjük a rossz választást, tehát azt, hogy nem vagyunk tévedhetetlenek. Minél jobban megbántuk döntésünket, annál harcosabban védelmezzük, mert annál inkább rászorul a védelemre. Két lehetôségünk van: egyfelól saját döntésünkról megpróbálni be- 
bizonyítani, hogy jó volt, másfelól a másik választási lehetôséget leértékelni, bizonygatván, hogy ha azt választjuk, az milyen rossz lett volna. Legalább a külvilág elôtt szeretnénk igazolni választásunkat. Ha pedig már a külvilág számára hihetó és elfogadható érveket találtunk rossz döntésünk mellett, elkezdjük magunk is elhinni óket. Ez pedig újabb kognitív torzításokhoz vezet, szinte vakságot okoz a valóság tényeivel szemben. Ennek a mechanizmusnak a kifejtésével adós marad a szerző.

A könyv négy részre és tíz fejezetre tagolódik. Három önvizsgáló kérdóív is színesíti a könyvet. 140 szakirodalmi hivatkozás, valamint egybedolgozott tárgy- és névmutató egészíti ki.

Hasznos olvasmány minden segítő foglalkozású embernek, akinek másokat döntési helyzetekben kell kalauzolnia. Közérthetố stílusa révén a múvelt laikus közönség számára is élvezetes. A tételek igazolására bemutatott pszichológiai kísérletek a kutatás gyakorlati hasznáról győzik meg a nagyközönséget.

\author{
Berghammer Rita \\ Semmelweis Egyetem, Magatartástudományi Intézet \\ 1089 Budapest, Nagyvárad tér 4. \\ E-mail: bergrit@net.sote.hu
}

Horányi Özséb (szerk.): A kommunikáció mint participáció

AKTI-Typotex, Budapest, 2007, 329 oldal, ára: $4200 \mathrm{Ft}$

ISBN 9639664333

Horányi Özséb kommunikációkutató, egyetemi tanár immár több mint egy évtizede foglalkozik önálló, általános kommunikációelmélet kidolgozásával. Elméletét a kommunikáció participációs felfogásának nevezi. Ennek lényege, hogy a kommunikáló - cselekvô - ember vagy társadalmi szervezódés a közösség rendszerében történelmileg és kulturálisan kialakult jelentések és szabályok szerint részt vesz valamilyen közös probléma megoldásában.

Horányi megközelítését azért nehéz bemutatni, mert minden fogalom, amellyel dolgozik, sajátos meghatározással bír, olyan általános értelmet kap, amely - a törekvések szerint - egy adott kommunikációs, illetve kommunikatív jelenségkör teljességére akar érvényes lenni. Horányi elmélete tehát magasan elvont, koncepciói speciálisak, tartalmaikban és egymással való összefüggéseikben is. Horányi és munkacsoportja folyamatosan munkálta ki ezt a különös szintézist a kommunikációról, részletei, elemei már több közleményben, könyvben megjelentek, de ez a kötet, amely most az eddigi írásokat mintegy összegzi (néhány korábbi írás részletei szerepel- 
nek a könyv függelékében, ezek olyan megfogalmazások, amelyek ebben a kötetben is használhatók modulként, építóelemként). A szintézis nagy területre terjed ki, Horányi a kommunikációkutatásban némileg szokatlan módon támaszkodik a filozófiára, különösen az ismeretelméletre, de alapjában a társadalomtudományok talaján áll, figyelemmel van a nyelvtudományra, különösen a pragmatikára, és számos alkalmazási területen is járatos, különösen a vallás és a múvészetek kommunikációs elemzésében.

Horányi nemcsak állhatatos és következetes kutató, hanem szerencsés is. A humán tudományok terén ma már ritka, hogy valaki ilyen kitartóan és szerteágazóan múveljen egy témakört, mint Horányi teszi, de ez azért is alakult ki így, mert bizonyos mértékig szerencse is kell hozzá, megfeleló szakmai érdeklődés és kutatási támogatás, továbbá a munkatársak és tanítványok elkötelezett csapata. Horányinak megadattak e szerencsés feltételek, egyetemi oktatásai nyomán tehetséges gárdát nevelt ki, akik közül már sokan ismert kutatók, és megfeleló anyagi forrásokhoz is jutott. Ez az összegző kötet pl. egy láthatóan nagyszabású és sok éven át tartó kutatási program révén valósulhatott meg, a támogatást az ORTT Stratégiai Kutatások és Elemzések Program adta, amelynek most az Alkalmazott Kommunikációtudományi Intézet (ATKI) a jogutódja, ez az intézet a kötet társkiadója is, láthatóan a kommunikáció területén már értékes és önálló profilt szerzett Typotex segítségével az általa támogatott kutatásokról sorozatot tervez. Az elsốdlegesen nyilván a médiában érdekelt támogató elismerést érdemel, hogy meglátta a participációs elmélet jelentôségét, mert ez a teória egyelôre még távol van a tömegkommunikáció világától, abban csak egy körülírt terület, esetleg még az elmélet általánosításaihoz illesztendó jelenségsor, illetve alkalmazás.

Az elmélet lényege tehát az erósen absztrakt alapfogalmak meghatározása és kidolgozása, és a köztük lévố kapcsolat modellszerú bemutatása. Értelemszerúen egy sor olyan alapfogalomról van szó, amely már a kommunikációkutatás hagyományában használatos volt, de most jelentéstartalmát specifikálni kell, és az összefüggések is már részleteikben vagy korlátozott viszonysíkokon ismertek, de itt sajátosan jelentkeznek. A kommunikáció elméletének ugyanis az az alapproblémája, hogy nem az objektív világ feltárása zajlik benne, hanem az emberi világ alapmodalitását, mátrixát jelentő kommunikáció reflexív kifejtése, átfogalmazása, elvont rendszerekbe vonása. Az emberi kommunikáció jelentős hányada és a belóle előálló szociokulturális kommunikáció túlnyomó része ugyanis önreflexív tudatossággal, és a kommunikációban részt vevők egyetértésének, konszenzusának nagyon összetett, dinamikus, hierarchikusan rétegzett rendszerében zajlik. A társas kompetencia alapfokára eljutó „egyszerú ember” 
is magasan tudatos kommunikátor, hiszen a kommunikatív viselkedés következményei nagyon is valósak és közvetlenek számára, ezek állandó kihívásokat jelentenek neki, és fokozatosan befolyásolják, fejlesztik. A társadalomelméletekben a Habermas által most hatékonyan megfogalmazott kommunikatív cselekvés koncepciója kezdettól fogva implikált módon a figyelem középpontjában áll.

Horányi - számos munkatársával - e kötetben három kulcsfogalom fénykörében bontja ki elméletét, az intézmény, az ágens és a színtér fogalmait veszi szemügyre. A rá már jellemzőnek mondható logikai rendszerben építkezik, decimális rendszerben fejti ki témáit. E könyvben munkacsoportja nagyon sok ábrát és betújelzést használ az összefüggések bemutatására. A fogalmazásmód - mint említettük - rendkívül elvont, bár Horányi mindent megtesz a pontos megértés érdekében, pl. igen gondosan közli forrásait, megfelelóen hivatkozik a használt szakkifejezések elózetes, kiindulópontnak vehetô meghatározásaira is. Eligazít az ismeretelméleti hátteret illetően.

Így is az értheti igazán ezt a szöveget, aki már kifejlódésében is követte Horányi elméletét. Magam már évek óta próbálom elsajátítani ezt a rendszert, számos kérdésben nem értem egészen, más vonatkozásban készen állnék megvitatására, azt azonban már bizonyosan állíthatom, hogy Horányi gondolatmeneteiben semmi sem felesleges és értelmetlen, alapvetóen minden érthetố is, a kérdójel mindig az absztrakció mértékével, érvényével, vetületével kapcsolatos. Bizonyos azonban, hogy a megközelítésmódot komolyan kell venni, és minden kommunikációkutatónak érdemes megpróbálkoznia - a maga vonatkoztatási rendszerében - az elmélet „egzegetálásával".

A kötet használójának azt tanácsolnám, hogy az olvasást ne - illetve ne csak - elölról kezdje. Horányi bevezetése inkább csak irányelveket ad (pl. megemlékezik az egész elemzési mód logikai, illetve nyelvészeti „, patkoltságáról” - ez Horányi kifejezése, a metafora nyilván arra utal, hogy a logikai, illetve a nyelvelméleti rendszerbázis teszi lehetôvé az elmélet „futását", mint patkó a lóét). A bevezetó is utal a függelékre, szerintem megéri a függelék olvasásával kezdeni. Itt négy tanulmány olvasható. A saját forrásanyag széles merítését mutatja a kommunikációkutatás történetéról szóló, már egy másik könyvben megjelent írás, ez azután részleteiben és kibontva késóbb megjelenik a szövegben. Ugyancsak van más, Horányi tollából megjelent, standardnak vehetô leírás a participációs elméletról, ez itt is hasznos. Még a függelékben nagyon érdekes, és mintegy elméleti „zenei kulcsot” adó két írás (Fekete Krisztián, illetve Horányi és Milován Andrea munkái) szól a rekonstrukció folyamatáról, ez két, erôsen elméleti 
tanulmány, az egyik a leírás és a magyarázat keretében, a másik a logikai és nyelvészeti hátteret érintôen vezet be - mélyen és sok tekintetben újszerúen - a kommunikációs elméletalkotásba. A kommunikációelmélet ugyanis par exellence rekonstrukció. A két utóbbi írás elkedvetlenítheti az olvasót, mert nagyon elvont és nehezen követhetô, de megvilágítja számára, mit jelent a logikai és nyelvészeti „patkoltság” , és adhat hermeneutikai eszközt a fó szövegtestek megértéséhez.

A könyv három részból áll. Az elsóben az intézmény értelmezését tárgyalják a szerzók (Pete Krisztián és P. Szilczl Dóra). Az intézmény a szociológiai illetve kultúrantropológiai tradíció legszélesebbre nyitott változataként szerepel, sajátos keret, amely emberi tevékenységet ösztönöz, fenntart, szabályoz, és amely közösséget képez. Az intézmények között említi a szöveg a nyelvet, a jogot, a morált, a vallást, múvészetet, tudományt, politikát és gazdaságot. A következó fejezet a színtér fogalmát mutatja be, ami nyilvánossági, illetve interakciós szituáció, jelentési kontextus, sajátos szabályrendszer. Végül az ágens meghatározását végzi el egy fejezet, ez talán a legbonyolultabb, e fejezetet Horányi akadémiai doktori és szerzőtársa, Szabó Levente PhD-disszertációjának alapjaként említi. A fejezet összetettsége onnan ered, hogy a szerzók a kommunikatív cselekvést végzố embert készségeiben, felkészültségében, a közös cselekvési aktushoz nyújtott inputjában is meg akarják határozni, anélkül, hogy megszemélyesíteni próbálnák, vagyis az ágens fogalmának alkalmazását szociális egységekre, szervezetekre nézve is fenn kívánják tartani. Lényegében az ágens - mondjuk így - belső, quasi kognitív és motivációs szerkezetének megállapítása sajátos rekonstrukció, ennek a szabályait igyekeznek a szerzók általánosságban leírni. Minden fejezetben kiemelt helye van a másik két alapfogalom (tehát pl. az intézmény esetében a színtér és az ágens) kapcsolódásának, és a tárgyalt fó kategória szerinti sajátos magyarázatának. Minden fejezetben szó van arról, hogy a kategóriáknak van ún. konstitutív alapjuk, amely az értelmüket, társadalmi és emberi jellegzetességeiket megadja, ennek jegyében legitimálódnak egyes jelenségek, pl. kommunikációs megnyilvánulásuk helyértékei, értelmezése.

A participációs kommunikációfelfogásban a fókuszban mindig az áll, hogy a társadalmi jelenségek reprezentációi, a szignifikátumok hogyan alakulnak ki, és hogyan aktualizálódnak a kommunikációs folyamatban. Az elmélet szerint a kommunikációs lényege mindig az, hogy a problémamegoldás törekvése kelt kommunikációs (részvételi) szándékot, és emiatt válik más ágens, illetve a közösség felkészültségi többletének igénybevétele fontossá. A probléma meghatározása a Horányi-féle teorémában az, hogy az ágens észleli, hogy a jelenlegi állapot és az optimálisnak vélt álla- 
pot között különbség van, és ezt meg akarja szüntetni. Ez a fố motiváló eró. Horányi különben igen nagy terjedelemben, illetve kelló részletességgel mutatja ki, hogy a kommunikációs filozófiájában mindig az emberi intencionalitás, vagyis a cselekvési célra irányuló szándék az ösztönzó tényezó, ez az ô elméletének is az alapfeltevése.

A három tényleges fejezet közül (a könyv igazában négy fejezet, de nem igazán jogos külön fejezetnek venni Horányi néhány oldalas bevezetójét) szerintem a legérdekesebb az intézmények bemutatása, a színteret nem érzem eléggé kidolgozottnak, és nehezen tudom követni - ha úgy tetszik, rekonstruálni - az ágenst elemzó fejezetet, miközben éppen itt van az egész koncepcióval kapcsolatos egyik fő kritikám: az ágensnek nincs (pszichológiai vagy szociális) „antropológiája”.

A másik fó kifogásom a problémamegoldási, illetve a részvételi paradigma kimerevítésével kapcsolatos. Nem tudom a problémaképletbe behelyettesíteni a kommunikáció különféle intencionális vagy funkcionális eseményeit, miközben akkor, ha a társadalmi kommunikációra, a közösségekre összpontosítok, akkor tudok emellett érveket felvonultatni. Az én világom a személyközi kommunikáció, és akkor nehezen tudom a participációs elmélettel magyarázni, hogy a megszületó csecsemó azonnal az anyai tekintetet keresi, mégpedig különösen akkor, mikor nem éhes, nem fáj neki semmi, tehát - ha úgy tetszik - nincs „problémája”, és azokra a tárgyakra tekint, amelyekre az anya néz (ezeket az átlagos anya valamilyen nemverbális jelentéstulajdonítással is ellátja, majd megnevezi óket). Mondhatjuk, hogy a világban a csecsemó akar tájékozódni, és akkor az egyetlen, kedves, elfogadható partner tekintete az érdekes, dehát - és ez a könyv fó problémája - akkor a végletekig feszítem és töltöm a kulcsfogalmak jelentéseit. Éppen itt van a kételyem, van-e értelme ekkora absztrakciónak, megalkotható-e ma a kommunikáció igazán alapvetô modellje. Tulajdonképpen a Shannon-Weawer modell gondja is ez volt, a szinte végtelenített absztrakció, és élénken emlékszem a szélsôségesen pozitivista, empirikus szociológia legmarkánsabb elméletalkotójának, Doddnak az álláspontjára, aki az ötvenes évek elején meghirdette, hogy a szociológiának a társadalom kvantitatív adatokkal kitölthetô alapképleteit kell megalkotnia, és gyökeresen szakítania kellene a klasszikus szociológia leíró elméleteivel - itt is végül nehezen értelmezhetó absztrakciókhoz jutottunk.

De hát ezt majd még végig kell vitatni, és előzetesen tovább kell figyelemmel kísérni Horányi és tanítványi köre munkáit, pl. az intézmények elemzését, amelyet már ugyancsak a Typotex kiadásában Korpics Márta és P. Szilczl Dóra meg is kezdett (a Szakrális kommunikáció címú kötetben). Horányiék könyve, elmélete, közelítésmódja a mai kommunikáció- 
kutatásban megkerülhetetlen, érdemes komolyan venni, aki elmélyed benne, annak nagyon sok perspektívát nyit meg, nem lehet tehát egyszerúen véleményt alkotni, itt az egész irányzattal kell foglalkozni.

\author{
Buda Béla dr. \\ Országos Addiktológiai Intézet \\ 1535 Budapest, Pf. 888 \\ E-mail: buda.bela@oai-addiktologia.hu
}

Tényi Tamás: Nietzsche és a pszichológia

Pécsi Tudományegyetem, Pécs, 2007, 159 oldal, ára: 1599 Ft

ISBN 9636421687

A szerzó újszerú és izgalmas kötettel lepte meg a pszichiátria-pszichoterápia múvelôit, de talán a humán tudományokkal foglalkozók érdeklődésére általában is igényt tarthat írása. Elmélyedt Nietzsche életmúvében, szinte mindent elolvasott, ami a nagy filozófustól - nálunk fóleg az utóbbi évtizedekben - megjelent, és megpróbálta azt a saját vonatkoztatási rendszerében értelmezni, amelynek kereteit a modern pszichoanalízis, és azon belül is a szelf pszichológiája adja.

A találkozás Nietzschével láthatóan revelatív erejú volt a szerzố számára, ezt nem csak az elószó árulja el, hanem az egész könyv stílusa is. A szöveg ugyanis - hasonlóan a szupervízióban gyakran tapasztaltakhoz - gyakran Nietzsche hullámhosszaira emelkedik, nemcsak nagyon elvont, de képi, metaforikus és szimbolikus kifejezésekkel teli, patetikus, filozofikus. Az előszó nagyon elgondolkodtató, mert a szerző egyfajta "midlife” átértékelésre - talán megvilágosodásra - utal, bizonyos, édesapjával kapcsolatos, de az olvasó számára közvetlenül nem érthetó évfordulót említ, és kifejezi azt a borzongást, amit az egybeesés jelent, hogy életkorának idejében Nietzsche zseniális szellemisége bezárkózott, és életének hátralévő 10 évét megszólalás nélkül, demensen élte le.

A gondolatmenet szuverén, rendkívül gondosan dokumentált, ez általában is jellemzó a szerzó múveire (a stílus azonban nem, hacsak az elvontságot és a filozófiai fogalomhasználatot nem tekintjük, mert a szerzó általában ezen a szinten szeret fogalmazni, de a jelen dolgozat sokszor szabad és csillogó színessége nélkül). Nietzschében a perspektivizmus és a konstruktivizmus előfutárát, Heinz Kohut szellemi elődjét látja, ugyanis Nietzsche a világ értelmezési rendszereit, amelyeket köztudott ontológiai síkokként fog fel, relativizálja, és a saját világnézetét elsősorban az érzelmek, a nehezen szavakba önthetô, szinte víziószerú tág, egzisztenciális élmény- 
módok, illetve az esztétikum szempontjaiban fogalmazza meg. Mint ismeretes, írásainak stílusa emiatt a költói, a meseszerú, az allegorikus, sót, gyakran a misztikus határterületein csapong. Bár a szerzó érti Nietzschét, és megértését a belsô összefüggések és megerôsítések felmutatásával tudja igazolni, mégis gyakran kell hermeneutikusan eljárnia, úgy, mint alchimisták vagy ezoterikusok írásai esetén szükséges.

Nietzsche érzelmi megértési koncepciója nyomán a szerző Kohut empátiafogalmának gyökerét véli benne felfedezni, és ahogyan Nietzsche ír a dolgokról, abban a szelf élményeit ismeri fel. Így Nietzsche gondolataiban - a szerzó kifejezését idézve - a test-szelf, az ideális-szelf, az apa-szelf stb. jelentéseit találja meg, és Nietzsche szemléletével összevethetónek érzi azt a folyamatot, amelyet a szelf-pszichológia - a gyermek konszenzuális (vagyis a gondozóival érzelmi és intellektuális összhangban lévô) világ-és énképének konstrukcióját magyarázandó - leírt.

A szerzó kiemeli a Dionüszosz-elméletet, amely Nietzsche egyik legfontosabb konceptuális súrítménye, teli implikációkkal, amelyeket írásai nyomán „egzegetálni” kell. Ezt a leírást ilyen alcímek jellemzik: „A sötétség egységétôl az ellentmondásokban szétdobottságig”, ,A Szelf sokrétűségben formálódó harmóniájáról", stb. (a szerző a szelfet nagy betúvel írja).

A „Lélek - mú - sors" címú második fejezet a gondolati fejlődést életfolyamattal veti össze, és itt is sokféle kapcsolatot talál (bár Nietzsche élettörténetében sokkal kevesebb lélektanilag releváns anyag található meg, mint amilyenekre a pszichoanalitikus biográfiai tanulmányok támaszkodni szoktak). E fejezetben fóleg a Dionüszosz-kép és filozófia evolúciója követhetó jól.

Dramatikus és érdekes Nietzsche betegsége, a harmadik fejezet. Itt a szerzố elénk tárja a szakirodalom vitáit: Nietzsche elborulását szifiliszes elmebajnak tulajdonították, újabban a cirkuláris betegség magyarázata is elójön (mint minden homályos nosológiai esetben ma szokásos - tehetnénk hozzá rosszmájúan...), a szerzó inkább a herediter frontotemporális demencia diagnózisát tartja valószínúnek, hiszen feltehetóen Nietzsche apja is ebben halt meg, és ez magyarázhatja az utolsó napokig megmaradt szellemi aktivitást, majd a hosszú túlélést, amely az esetleges agydaganatot mint lehetséges kórokot kizárja (Nietzsche szifiliszes fertózéséról nincs adat). Mindenesetre a betegség a különös életmú sajátságos befejezése, dramatikus vége.

Nagyon érdekes a „Dionüszosz és a Szóke Bestia - Nietzsche és Jung” címú fejezet. Ez Jung különös viszonyát mutatja be a filozófushoz, amely rá is hatott, és e fejezetból is úgy túnik, hogy Jung tóle vett bizonyos archetípusokat, amelyeket azután saját életmúvébe illesztett. Jung sokban, és életmúve során gyakran követi ugyanazt a szabad - a gyanútlan olvasó akár 
úgy érezheti: felelótlen - általánosításokkal dolgozó fogalmazásmódot, ami Nietzschére jellemzó. Emberról, univerzumról, sorsról magvas és szédító kijelentések sorjáznak ebben a stílusban. Jung egyébként éveken át tartott Nietzsche-szemináriumokat, amelyeket tanítványai lejegyeztek, de ezeket az írásokat Jung sokáig - szinte élete végéig - nem engedte közzétenni (csaknem 1600 oldalnyi szövegról van szó!).

A „Tudattalan - Nyelv - Szubjektum” címú fejezet, éppen a Jung-recepció ellentételezésében fogalmazva azt fejti ki, hogyan próbálta Nietzsche a nyelv kötelékeit is lerázni magáról, és ezzel a gondolat teljes szabadságát elérni, mert a világszemlélet hagyományos nyelvi kötöttségeire - ha ugyan kritikusan és implikatív módon is - de többször rámutatott. Ezután már csak két rövid fejezet következik a könyvben a hatalmas irodalomjegyzék elótt, egyik a szépíró és patetikus Nietzschét elemzi irodalmi múvei, fóleg versei nyomán, itt a Velence motívum kerül elótérbe, amellyel a zenét jellemzi, és amely a hullámzás különös szimbolikáját állítja a középpontba; egy másik, utolsó fejezetben pedig a szövegben végig alapvetó fontosságúként tárgyalt, a Zarathustrában megfogalmazott örök visszatérés motívuma nyer részletesebb elemzést, két pszichológiai jelenség nyomán, amellyel kapcsolatosan a szerzó saját tanulmányokat is írt, egyik a „kísérteties" (a Freud-féle das Unheimliche) a másik a Capgras szindrómában központi „hasonmás” motívum. A „kísérteties” érdekessége, hogy Freud az ismétlési kényszer jelentkezésének átélési formáját próbálja ezzel leírni, és itt a pszichoanalitikus elemzés ismét összekapcsolódik olyan filozofikus - a léttel, a sorssal összefüggó - mozzanatokkal, amelyekkel Nietzsche is vívódott.

A könyv magával ragadó, noha nehéz olvasmány. Egyike azoknak a munkáknak, amelyekról már az utolsó lapoknál lehet tudni, hogy ezt nemcsak el kell újra olvasni a teljes megértéshez, hanem ezt érdemes is megtenni, mert új értékekhez, gondolatokhoz vezet. Csak gratulálni lehet tehát a szerzónek, aki a szakmai középnemzedék kiemelkedóen tehetséges és alkotó tagja, és aki a modern pszichoanalízis kitúnó ismerójeként foglalkozik a pszichózisok és a határeset-szindróma jelenségeivel és terápiájával. Minden írása figyelemreméltó és - mint már említettük is - kitúnó, szakirodalmi alapjait illetóen pedig szinte teljesen dokumentált.

A befejezetlenség érzése mellett, amit a könyv kelt, azért néhány kritikai szempont is feltolul az olvasóban. A fontosabbak a következók:

1. Talán a cím nem jó. Nietzsche és a pszichoanalízist kellene írni. Bár kétségtelen, hogy Nietzsche megértéséhez a pszichoanalízis adja a legfontosabb kulcsot, talán mondhatnánk, a pszichózisok pszichoanalízise, mert itt van meg a türelem a látszólag értelmetlen szavak és mondatok analóg, szimbolikus vagy asszociatív magyarázatához, a kontextusok aprólékos 
megkereséséhez, de azért a lélektan nagy diszciplínája, amelybe belesorolom az antropológia és a szociológiai társaslélektan ismereteit is, bőséges támpontokat ad a tárgyalt perspektivizmushoz, vagy éppen a konstruktivizmushoz. Csak vegyük példának az empátiát, ennek eszmei forrásvidéke sokkal nagyobb, mint hogy e vetületben Nietzsche és Kohut közötti vonallal a geneológia lerövidíthető legyen. Nagy munka, és talán értelmetlen is Nietzschét nagyobb lélektani távlatban elemezni, de hát a cím mintegy ezt ígéri.

2. Láthatóan a szerzó vonzódását Nietzsche iránt az újabb pszichoanalitikus irodalom megnövekedett érdeklődése inspirálta. Így is azonban egyszerúsítés a szelfet mint általános magyarázó elvet, mint konceptuális csodafegyvert használni, eltekintve attól, hogy itt is sokkal hosszabb és szerteágazottabb a fogalom történeti gyökerezettsége, akár még a pszichoanalízisen belül is, mintsem hogy Kohut itt hirtelen elókerüljön, és általános keretté váljon. A szelf ilyen „aduként” történó interpretációs felhasználása a klasszikus logika „clarus per obscurius" hibalehetőségét veti fel. Tudjuk, hogy a szelf valamiféle konstrukciós értelmezés, de sem az identitás felé, sem pedig az ósi Hartmann-féle (konfliktusmentes) pszichoanalitikus én, illetve a narcisztikus megszállás nyomán Freud által elképzelt „libidinózus” én felé nem megfelelően elhatárolt fogalom. Emellett a „pauschal" felhasználása csak „csóvál” egy nagyon bonyolult, implikációkkal túlterhelt szignifikátumot, hiszen senki sem tudja még a szelf múködését, szerkezetét, változási dinamikáját stb. Kicsit hasonló a helyzet, mint a pszichoterápiákban a "rendszer” fogalmának használatával kialakult gyakorlatban. A családterápiában figyelhetố meg, mennyi mindent értünk bele e fogalomba, közben a nyílt rendszerek általános modellje hiányzik, és lényegében csak a homeosztatikus szabályozás és a visszacsatolás fogalmi heurisztikuma a nagy magyarázó eró, amely miatt az „,adeptusok" - de fóleg a képzésben lévók - szent szóként emlegetik. Érdemes végigolvasni ezt a könyvet úgy, hogy közben megkérdezzük magunktól, jó-jó, de hát mi is igazában a szelf. A 24. oldalon és környékén vannak idézetek Nietzsche énnel kapcsolatos megállapításaiból, nagyon hiányzik, hogy a németül láthatóan tudó szerzó miért nem próbált utánamenni, hogy használta-e és hogyan a filozófus a Selbstet, amely a szelf történeti óse, akár Jungot, akár a Horney vagy a Bühler házaspárt is nézzük (e két utóbbi nagy szerepet játszott a szelf fogalom elterjedésében, ezt Kohut csak elóvette, "okkupálta”, , "pszichoanalitikusan megszállta”, és most már itt az ô nevéhez füződik minden).

3. Hatvany Lajos „Die Wissenschaft des nicht Wissenswerten” címú könyve annak idején hatást gyakorolt rám, és megmentett attól, hogy klasszika-filológus legyek, miközben pedig már bensóséges viszonyom volt la- 
tin, görög és héber textusokkal, szövegkritikai kiadásokkal és archeológiai problémákkal. Valahogy telítődtem, és a "tudni nem érdemes dolgok tudományával" felhagytam. A pszichoanalízis mai vallásos kultusza, filológiai akríbiája, hagiográfikus személyábrázolása, és a tudattalan valóban mitologikus kezelése (Freud ugyan az ösztöntant nevezte a „mi mitológiánknak", de erról csendben elfeledkeztek követôi) ugyanezt a telítódést hívja eló bennem, csak már késó, hogy ezzel felhagyjak. De kultiválni azért nem szeretném tovább. Nietzsche értelmezésében most a fundamentalista gyülekezetek bibliai szövegértelmezését, a hívố marxisták talmudikus elmélyülését, a vörös könyv mindenre érvényes mondanivalójának egyfajta újrakreálását érzem. Nietzsche teli van lapidáris megállapításokkal, pl. egy félmondata: „ha feltételezzük, hogy az igazság egy nô...” (15. old.), óriási interpretációs távlatokat nyit meg a szerzố számára is, bennem felidézi Otto Weininger "Geschlecht und Charakter" címú hatalmas múvét, amelyet értelmét keresve - egykor átrágtam. De tényleg van ennek értelme? Megérnek ezek a kusza gondolatok ennyi fáradtságot? Van pl. Nietzschének tényleg heurisztikus tartalma, azon kívül, hogy eszmetörténetileg, hatásaiban és recepcióiban bizonyára érdekes az egész, és a nyugati filozófia mondjam malignusan: „hamistudati” - áramlatainak egyik érdekes vonulata, ha akarom hullámzása, Velencéje, bizonyos értelemben örök visszatérés?

De hát ez már messze vezet. Viszont jó lenne ezekról értelmes dialógusokba bocsátkoznunk. Ha ezt a könyvet sokan elolvasnák, talán lenne erre mód. Talán én is korrigálnám eretnekségemet, amelyhez a zabolátlan kétely mételye, hogy én is nietzcshés legyek, elvezet.

A könyvet a Pécsi Tudományegyetem adta ki, tipográfiájában, küllemében nem teljesen szerencsés módon. Több helyen kapható, Pécsen kívül az Animulában is.

Buda Béla dr.

Országos Addiktológiai Intézet

1535 Budapest, Pf. 888

E-mail: buda.bela@oai-addiktologia.hu 
Antalfai Márta: A nối lélek útja mondákban és mesékben

Új Mandátum Könyvkiadó, Budapest, 2006, 332 oldal, ára: 2890 Ft ISBN 9639609471

Érdekes, izgalmas szakkönyvet tarthat kezében az olvasó, melynek bizonyos értelemben megvannak a maga közvetlen, magyar nyelven is hozzáférhetố elózményei - pl. Marie-Luise von Franz vagy Clarissa Pinkola Estes nói mesealakokat, jungi archetípusokat vizsgáló elemzései -, másfelól ilyen széles körú magyar meseanyagon, mitológiai párhuzamok bevonásával, illetve egyetlen magyar monda alapos, jungi szemléletú mikroelemzésével még nem találkozhattunk.

Komoly erénye a könyvnek az is, hogy az elméleti szakember és a klinikai szakpszichológus - a maga hatalmas tapasztalati anyagával - egyaránt megszólal benne; az egyik aspektus erósíti a másikat.

Szinte hihetetlen, hogy a Jókai Mór által feldolgozott monda, Az istenhegyi székely leány súrített formában magában foglalja a nói személyiségfejlődés 9 szakaszát, melyek külön-külön is megjelennek különféle, nói főszereplővel rendelkező mesékben. Egy 2554 mesemintából kigyújtött 255 nói fószereplős meseanyag ugyanezt a 9 kategóriát rajzolja ki; sorrendben: a testvérek, az okos lány, a jószívú lány, a mostohák, a próbatételek, a sárkányok, a boszorkányok, az átváltozások és a párkapcsolat - egy-egy, tipikus életszakasznak megfeleltethető - kategóriáját.

A szerző összeveti a monda főszereplóje, Ilona (Lóna és Szendile) által képviselt nóiség fázisait a jungi, wolffi és boleni archetípusokkal is (vö. még Neumann), ugyanakkor tovább is lép, mivel „egyik fent említett szerzónél sem szerepel a nói archetípusok fejlódési trendben történő megjelenésének megfigyelése, illetve leírása".

A négy jungi pszichés alapfunkció - némi nyelvi játékkal: az érzékelés, az érzelem, az értelem és a megérzés - és az elemzésre kerüló archetípusok szoros összefüggést mutatnak egymással, mind a meseelemzésekben, mind a választott monda elemzésében.

A monda szereplôi egy-egy archetípust, másfelól egy-egy domináns tudati beállítottságot jelenítenek meg. A cselekmény a fóhósnó személyiségfejlődésének fázisait mutatja be a kora gyermekkortól a korai felnôttkorig. A történet folyamán a fóhősnó megszabadul mind a (halott) apa, mind a (korán elvesztett) anya archetípusának, valamint animus lélekrészének fogságából, majd - miután csábító-szeretó-aphroditéi nárcizmusától is - a monda végére éretté válik a párkapcsolatra.

A könyv függelékben tartalmazza Az istenhegyi székely leány c. mondát, valamint további 13, nói archetípusokat, gyakori komplexusokat megjelenítő mesét, így bármikor odalapozhatunk az elemzések közben is. 
Antalfai Márta könyve, melyet Zátonyi Tibor gyönyörú borítója miatt már kézbe venni is nagy öröm, szinte minden nónek kötelező olvasmány. Ha nyitott lélekkel, figyelmesen, érzékelve- érezve-értve olvassuk, tovább is léphetünk életfeladataink útján.

Úgy érzem, mitopoétikus utalásaival, irodalmi hivatkozásaival, Jung és követôi rendszerezéseivel szinte heurisztikus erôvel segítheti a szakkönyv minden terapeuta munkáját is.

\author{
Dr. Spannraft Marcellina \\ E-mail: spann@freemail.hu
}

Michael E. McCullough - Steven J. Sandage - Everett L. Worthington:

Megbocsátás. Hogyan tegyük múlt idóbe a múltunkat?

Fordította: Falus Eszter

Harmat Kiadó, Budapest, 2005, 262 oldal, ára: 1980 Ft

ISBN: $963956446 \mathrm{X}$

Hiánypótló kötetet vehet a kezébe az olvasó: a kötet - mely angol nyelven 1997-ben jelent meg - a hazai pszichológiai szakirodalomban elsóként foglalkozik a megbocsátás témakörével. Annak ellenére, hogy a vallás és a filozófia régóta foglalkozik a megbocsátás témájával, a pszichológia tudománya csak az utóbbi évtizedben - az ún. pozitív pszichológia megjelenésével és megerôsödésével párhuzamosan - kezdte el ezt vizsgálni.

A szerzók definíciója szerint a megbocsátás: „,annak az elhatározásnak az erôsödése, hogy egy jó szándékon és bizalmon alapuló kapcsolatot helyreállítsunk valakivel, aki megbántott bennünket" (24. o.). A megbocsátást meg kell különböztetni a kegyelemtól (ami jogi fogalom), a mentségkereséstôl (ami enyhítő körülményekre való hivatkozást implikál), a felejtéstól (ami a sérelemre vonatkozó emléknyom elhalványulását jelenti) és a tagadástól (ami arra vonatkozik, hogy a személy nem tud vagy nem akar szembenézni az ôt ért sérelmekkel). Az utóbbi években számos kutatás vizsgálta a megbocsátás gyökereit és fizikai, illetve mentális egészségre kifejtett hatását. Számos intervenciós tréninget, programot dolgoztak ki, melyek célja a megbocsátás képességének elősegítése.

A kötet szerzói a tudományos megbocsátáskutatás elismert és kiemelkedó tekintélyei. Annak ellenére, hogy - saját bevallásuk szerint - mindhárom szerzó keresztény elkötelezettségú, múvükben a megbocsátás témáját nem a keresztény teológia, hanem a pszichológia nyelvén tárgyalják.

A kötet bevallott célja az információközlésen túl az, hogy segítségével „javítsunk életünk minôségén” (14. o.). Ennek érdekében számos gyakorlatot találunk a kötetben, melyek segítségével az olvasó a megbocsátáshoz 
kapcsolódó készségeit fejlesztheti. A közérthetôség érdekében a szerzók kerülik a tudományos nyelvezetet. Az empirikus, tudományos részletek iránt érdeklődố olvasók a hivatkozott irodalmat használhatják további tájékozódásra. A kötet hangvétele rendkívül személyes: az „illusztratív” történetek közül - az irodalmi és történelmi példák mellett - számos a szerzők személyes élettörténetéből került ki. Minden fejezet végén összegzés található, mely hatékonyan segíti az olvasottak megértését és integrálását.

A magyar nyelvú kiadáshoz dr. Túry Ferenc írt elószót. A bevezetést összesen 15 fejezet követi. Az elsó fejezet a megbocsátás definíciójával foglalkozik, valamint bemutatja a könyv központi gondolatát, miszerint „a megbocsátás a teljes személyiséget érinti" (25. o.). Éppen ezért a megbocsátás kiterjedt változásokkal jár személyiségünkre és kapcsolatainkra nézve. A második fejezet a megbocsátással kapcsolatos erkölcsi döntés kérdését járja körül. Ha erkölcsi érzékünket sértô esemény áldozataivá válunk, ellentétes morális normák „kereszttüzében” találjuk magunkat. A mérleg egyik oldalán a felelősség és igazságosság, a másik oldalán az empátia, részvét állnak. A megbocsátás olyan erény, mely magában foglalja az igazságosság és a kegyelem, empátia egyensúlyát. A harmadik fejezet a megbocsátás képességének fejlődése és a kognitív fejlődés közti kapcsolattal foglalkozik. A kognitív fejlődés Piaget által bemutatott szakaszainak analógiájaként Robert Enright pszichológus leírta a megbocsátás képességének hat fejlódési szintjét (a legmagasabb szintú megbocsátást a „szeretetból fakadó megbocsátás" képviseli). A szerzók szerint kognitív (és az ehhez kapcsolódó morális) fejlódésünkkel párhuzamosan fejlődik a megbocsátásról alkotott felfogásunk. A következó (negyedik) fejezet a megbocsátás kognitív - racionális megközelítésének korlátaival foglalkozik. A megbocsátás fejlődése sokszor "szabálytalan”, nem lépésról lépésre, szintról szintre halad elóre. Emellett a racionalitás mellett több - személyes, társadalmi és spirituális - tényező összjátékából alakul ki a megbocsátás képessége. Az ötödik fejezet a sérelmekre adott lehetséges reakciókat mutatja be. Részletesen kitér az olyan gyakori (és kevéssé adaptív) reagálási módokra, mint a bosszúvágy, a cinizmus és a felelôsség átruházása. A hatodik az interperszonális konfliktusok dinamikájával foglalkozik. Különbözó sérelmek felhalmozódása esetén sokszor elég egyetlen konfliktus ahhoz, hogy eljussunk a megbocsátásra való képtelenség állapotába. Ugyanakkor a megbocsátás ugyanilyen gyorsan helyre is tudja állítani a sérült kapcsolatot. A következő (hetedik) fejezet azokat az agyi és mentális folyamatokat mutatja be, melyek megnehezítik a megbocsátást. Egyrészt az idegrendszerünkben "tárolt" emléknyomok és érzelmek, másrészt az elme tudattalan védekezése a sérülésekkel szemben tarthatja fenn a bosszúvágyat és nehezítheti meg a megbocsátást. A megbocsátáshoz változtatnunk kell emléke- 
inken, érzelmeinken, és empatikusabbá kell válnunk. A nyolcadik fejezet a megbocsátás és az emlékezet összefüggését tárgyalja. Múltbeli sérelmeinket hiába próbálnánk elfelejteni - emlékeinek azonban módosíthatóak, „felülírhatóak". Ehhez számos gyakorlatot mutat be a fejezet. A következó (kilencedik) fejezet a megbocsátás hátterében álló lehetséges motivációkat tekinti át. A „valódi”, belülról fakadó megbocsátás az empátiás képességből fakad, így a „megbocsátás az empátia képességének erősítésével fejleszthetó" (157. o.). A tizedik fejezet a narratív pszichológia szempontjából elemzi a megbocsátás jelenségét. A narratívumokban a megbocsátás kulcsfordulatot jelenthet, „, mivel ez képes a szeretet és remény történetévé alakítani a keserúség és a kétségbeesés történetét" (175. o.). A tizenegyedik fejezet az önváddal, bûntudattal és az önmagunknak való megbocsátással foglalkozik. A következó fejezetben a szerzók a megbocsátás egyik fontos segítô tényezójét, a bocsánatkérést mutatják be. A bocsánatkéréshez négylépcsôs folyamat vezet: empatikus odafigyelés a másikra, empatikus bưntudat, a búnbánó beismerés, és végül a békülés kezdeményezése. A tizenharmadik fejezet a megbocsátás következményeit mutatja be. A megbocsátás aktusa javítja a fizikai és mentális egészséget, növeli a kontroll-érzetet és javítja az életminőséget. Több kontrollált vizsgálat szerint a megbocsátásra hajlamosabb személyek alacsonyabb szorongás- és depresszió-szinttel jellemezhetőek. Az A-típusú viselkedésmintázat gyengítésén keresztül a megbocsátás kedvezóen befolyásolja a testi egészséget is. Meglepó módon nem csak a megbocsátás, hanem a búnösség beismerése és a bocsánatkérés is kedvezóen befolyásolja egészségi állapotunkat. Hatásai alapján a szerzók a megbocsátást „egyfajta természetes kognitív terápiának" (212. o.) tekintik. A tizennegyedik fejezetben a szerzók a megbocsátást a párkapcsolatok és családi kapcsolatok kontextusában vizsgálják. Számos vizsgálat eredményét összegezve megállapítják, hogy az egymásnak megbocsátani kész partnerek jobban bíznak egymásban, jobban szeretik egymást, jobban el vannak kötelezve egymás iránt, és összességében elégedettebbek kapcsolatukkal. A kötet kitér a megbocsátás szerepére a családon belüli erốszak, abúzus esetén. Ezekben az esetekben a sértett gyakran azt gondolja, hogy a megbocsátás véget vet a bántalmazásnak, és segít helyreállítani az elkövetóvel való kapcsolatát. Legtöbbször azonban a helyzet ennél sokkal bonyolultabb: „igazságot kell szolgáltatni, a vétkesnek rehabilitáción kell részt vennie, és őszintén, huzamos időn keresztül kell bizonyítania változás iránti vágyát" (235. o.). Ezekben az esetekben a megbocsátásnak az utolsó és nem az egyetlen lépésnek kell lennie. A záró (tizenötödik) fejezet azt vizsgálja, hogy a megbocsátás hogyan csökkentheti a csoportközi (országok, rasszok, népek stb.) konfliktusokat. A megbocsátást ezekben az esetekben több tényező nehezíti. Egyrészt nem lehet 
egyetlen vétkest megnevezni, így seregnyi névtelen elkövetőnek kell megbocsátani. Másrészt a konfliktust eredetileg kirobbantó vétkek gyakran a múlt homályába vesznek, és az emlékezetben már csak „a megtorlás véget nem éró körforgása marad meg" (240. o.). Mindezek ellenére történnek próbálkozások a csoportközi konfliktusok megbocsátás segítségével történô rendezésére (ilyen volt például a Libériában egymással háborúban álló törzsi csoportok „összebékítése”). Ugyancsak ez a fejezet foglalkozik a megbocsátás potenciális szerepével az igazságszolgáltatásban. A szerzók felvetése szerint a búncselekményt követően az ôszinte megbánás kifejezése, illetve a megbocsátás aktusa mind az elkövetó, mind pedig az áldozat számára rendkívül hasznos lenne mentálhigiénés szempontból.

A kötet igen széles olvasó közönséget céloz meg. A laikus olvasó számára a közérthetóség és a személyes hangvétel teheti vonzóvá a múvet, a segító foglalkozásúak (pszichológusok, szociális munkások, mediátorok stb.) hatékonyan használhatják a könyvben bemutatott gyakorlatokat, feladatokat, a kutatók pedig számos inspiráló gondolattal találkozhatnak.

Összességében fontos és színvonalas múvel gazdagodott a hazai pszichológiai szakirodalom. Reményeink szerint a könyvet több hasonló mú követi majd, és a megbocsátással kapcsolatok ismeretek mihamarabb beépülnek mind a közgondolkodásba, mind pedig a mindennapi pszichológusi munkába.

\section{Szondy Máté}

ELTE PPK Személyiség- és Egészségpszichológiai Tanszék

1064 Budapest, Izabella u. 46.

E-mail: szondymate@gmail.com 